"Looking all lost towards a Cook's Guide for Beauty": The Art of Literature and the Lessons of the Guidebook in Modernist Writing

Suzanne Hobson*

*s.hobson@qmul.ac.uk

\title{
Abstract
}

This article explores the impact of the guidebook, especially the Baedeker series, on modernist literary culture. It argues that the guidebook is a literary phenomenon in its own right and that, as such, it attracts special attention from those engaged in defending and/or extending the category of literature as part of a modernist agenda. In particular, modernist writers are concerned as to whether the guidebook counts as a form of literature and, if so, what this means for the more familiar forms seen in their own essays, fiction and travelogues. What might the invention of the star-system to rank scenes and monuments mean for the future of art criticism? How might the guidebook help or hinder the traveller in her pursuit of the beautiful or the picturesque? What does recourse to the guidebook reveal about the taste and education of the traveller? And, more pointedly still, what kind and quality of writing is the guidebook itself? This article surveys the extent of modernism's interest in the guidebook, both as a noteworthy new form and as a form modernist writers adapted for use in their own books, before turning in detail to commentary on the guidebook in E.M. Forster, Ernest Hemingway, H.D. and Virginia Woolf. In conclusion, it finds that the guidebook in modernism is very rarely just that. 1 
Instead, the guidebook finds unexpected affinities with modernism in its attempt to "modernise" literature - to make it more rational, more totalising and, in the eyes of its critics, less able to discriminate.

Keywords

Guidebooks; modernism; Virginia Woolf; E.M. Forster; H.D.; Ernest Hemingway; Mina Loy; tourism; literature; fiction.

Guidebooks are difficult to place in relation to other genres of writing. As Debbie Lisle suggests, they seem closest to travel writing, but whereas travel writing vacillates between fact and fiction, "guidebooks must list mundane facts". Travel writing is thus more "sophisticated" than the guidebook and ranks higher in the "hierarchy of literature", which has fiction at the top, travel writing in the middle and the guidebook at the bottom (Lisle 2006, 30). The guidebook comes up short against other measures of literature too: instead of narrative, it offers the economies of the itinerary and the list; instead of style, a "sign-post" language; and its voice, collective rather than singular, seems, impersonal even inhuman. And yet the case for the guidebook as literature is by no means already lost. As this article will suggest, there are some who argue that the guidebook simply is a "branch of literature" and others who suggest that the guidebook's perceived shortcomings (especially economy of presentation and sign-post language) are the hallmarks of a new kind of writing, a modernised form of literature (Forster 2004, 356). This second possibility is itself open to dispute so that the guidebook is seen alternately as the standard of what 2 
literature must become to adapt to a modern readership and/or a sign of what, without vigilance against the tendencies identified above, literature will inevitably be reduced to.

These divided attitudes towards the guidebook are strongly represented among modernist writers based in Europe and America in the 1920s and '30s. T.S. Eliot, E.M. Forster, Ernest Hemingway, Mina Loy, Ezra Pound, Wyndham Lewis, H.D. and Virginia Woolf, among others, are all quick to make pointed and pejorative references to the guidebook, especially the Baedeker, which seems, by this measure at least, to have been unrivalled in the early twentieth century in terms of visibility and market penetration. ${ }^{1}$ Yet to conclude based on this evidence that modernists have no use for the guidebook would be premature. The list of writers above includes several who were guidebook authors in their own right (Hemingway and Forster), as well as selfconfessed fans of the Baedeker (Pound, Forster and H.D.), and imitators, so to speak, of guidebook idioms and forms (H.D., Forster and Eliot). Scholars have often remarked with reference to modernism that the tourist with Baedeker in hand serves as a sign of the times - a convenient marker of a new ethos in travel frequently rational in approach and democratic in spirit. Stan Smith, for example, reads Eliot's "Burbank with a Baedeker: Bleistein with a Cigar", as an expression of the "ethos of the American tourist abroad" while Alexandra Peat discovers among the tourists in Forster and other novelists "a new spiritual ethos for the modern age" (Smith 2004, 14; Peat 2010, 2). According to James Buzard, the visibility of tourism in this period meant that "snobbish anti-tourism" became an "exemplary way" for the modernist writer to establish the authenticity of his or her own travels $(1993,5)$. In this context, 3 
the guidebook often functions as a badge marking the tourist as distinct from the traveller, or, if given more particular consideration, it becomes the textual equivalent of the tourist's own supposed failings, manifesting in written form the same tendency to surface-skim, to rush too quickly from one sight to another and to accept without question the received-view of a place.

In this article, I consider the guidebook in its own right as a literary phenomenon that, as such, attracts special attention from those engaged in preserving and/or extending the category of literature as part of a modernist agenda. By this, I mean the project loosely identified by Lawrence Rainey, Lois Cucullu, Gail Macdonald, Rod Rosenquist and others as the "institutionalisation of modernism" (Rainey 1998; Cucullu 2004; McDonald 1993; Rosenquist 2009)—the attempt, on behalf of a select group of writers, to consolidate and to market particular texts as "the voice of a 'movement' of our modern experiment since 1900" (Pound as quoted in Rainey 2005, 76). As Lois Cucullu points out, such efforts are entirely consonant with a general move towards specialisation in the early twentieth century: "modernists obey the same cultural logic as do experts of disciplines that systematically professionalise themselves. And modernists do so in order to guarantee their truthtelling office as an autonomous and indispensible domain of modern culture" (2004, 35). It is now widely accepted that this logic does not always hold up against the facts of modernist production and dissemination; modernists had much to learn from popular forms and, as the frequent references to the Baedeker suggest, they found much to inspire them there too. And yet, this logic does perhaps explain why some thought it important to distinguish between Baedeker-learning and modernist 
expertise in those areas where they thought to compete with the guidebook. Denigrating the guidebook (or the straw-man that is the Baedeker-schooled expert) becomes a means of establishing one's own credentials or of reminding readers that travel writing is itself a branch of literature not to be confused with, far less exchanged for, the guidebook.

In this article, I focus primarily on self-reflexive comment on the guidebook, which assumes, firstly, that the form is a variation on the travel essay or the work of fiction and that, secondly, as a consequence of this fact it falls to the essayist or the novelist to situate her own literary expertise in relation to that on offer in the Baedeker. The questions asked of the guidebook in this context frequently demand much more of this genre than mundane facts and speak equally to anxieties about what literature is (if it is still anything at all) as to whether the guidebook is fit to join its ranks. What kind and quality of writing is on offer in the guidebook? What are the aesthetic criteria against which it tests the monuments and art works discussed? Does the guidebook's preference for the beautiful and the picturesque lag behind contemporary standards of aesthetic judgement? And what does recourse to the guidebook reveal about the taste and education of the reader? Later in the essay, my focus moves to the use that modernists such as Forster, Hemingway and H.D. make of the guidebook in their own fiction. It stands to reason that writers who were keen readers of guidebooks would find there a readily available source of information about the foreign cities and landscapes described in their books. But some of them found a methodology there too, a new kind of language and style as well as new approaches to writing space and time. In some ways, the effort that these writers put 5 
into answering to and for the guidebook seems unnecessary — after all, it would take a particularly indiscriminate reader to mistake the content of a guidebook for that of a novel or a travel essay. But the point of this investment may not merely have been to safeguard a self-evident distinction between the literary and the informational. The modernist argument with the guidebook serves in part to produce the difference it sometimes claims is under threat of disappearance. In other words, the aim is less to challenge the perceived cultural hegemony of the guidebook than to establish exactly what the reader gets in the way of instruction and pleasure from reading travel novels and essays that he/she cannot get from reading Baedeker, Murray or Michelin.

Anglo-American modernism shared its most celebrated years (the 1920s and '30s) with what has sometimes been called the golden and "final age" of travel writing (Fussell 1980, 50-64). The historical moment is not all, however, these genres have in common. Since Fredric Jameson's classic essay, "Modernism and Imperialism", modernism has been widely understood as a colonial literature exhibiting some of the same formal characteristics (the spatialisation of form and the impulse to totalise) as travel writing and guidebooks (2006). Recent scholarship has focused more directly on the family resemblances between modernism and travel writing (Carr 2002; Youngs 2010). The similarities are not always easy to discern because travel writing is often dismissed as credulous or naïve where modernism is ironic or knowing, outward-focused (aiming for objectivity) where modernism looks inward, and mono-vocal where modernism typically showcases multiple voices or viewpoints. ${ }^{2}$ And yet, as David Farley points out, it only takes a small shift in position to see how the very features that supposedly distinguish modernism from travel 6 
writing might owe a great deal to the modernist experience of travel and more specifically to the attempt to write about this experience: "fragmented forms, montage techniques and stream of consciousness owe much to foreign scenes, exotic locales and the wrenching perspectives and uncanny displacements of a generation enlivened by foreign travel" $(2010,1)$. Farley points out that Ezra Pound once had ambitions to write a travel book and, although he later abandoned this project, the experience informed his treatment of history and place in the Cantos. E.M. Forster and Ernest Hemingway wrote their own guidebooks (respectively Alexandria: A History and a Guide [Orig. pub. 1922] and Death in the Afternoon [Orig. pub. 1932]) and as Allyson Nadia Field points out, many of Hemingway's novels resemble "insider guides" to the fashionable destinations in which they are set $(2006,31)$. Even the most modernist of modernists - writers whose idiosyncratic prose and intractable attitudes would seem least adaptable to the demands of travel reportage - turned their hand to guidebook writing and found they hardly needed to alter their style to do so. Wyndham Lewis's Filibusters in Barbary (Orig. pub. 1932) is a guidebook (of sorts) to North Africa as well as a satire on the contemporary intellectual and political scene. Gertrude Stein's Paris, France (Orig. publ. 1940) describes French domestic habits in the highly stylised prose for which she is notorious. Perhaps, then, it is the very proximity of modernism to the guidebook that gives rise to the need to make a difference, to the necessity of pinpointing exactly what the reader gets from Forster, Lawrence or H.D. on Italy, Pound on France or Hemingway on Spain that she cannot get from the Baedeker. The need may have seemed more pressing because, put simply, there is a 
great deal in Forster and H.D.'s Italy, Pound's France and Hemingway's Spain that did, in fact, come straight from the pages of Baedeker.

\section{Pleasure and Instruction}

Travel writing has long had a part to play in the improvement and acculturation of the traveller. The eighteenth-century grand tour was conceived as a means of finishing a young gentleman's classical education and of schooling him in taste. Travel writing from this period often manifests a similar purpose. The authors borrow from contemporary treatises on aesthetics and mobilise a technical vocabulary that still circulates, though with less philosophical baggage, through travel writing today. Nigel Leask, for example, identifies an "aesthetic of curiosity" in eighteenth-century travel writing, which pays lip service to, even as it modifies, philosophical treatises on aesthetics (2000). Benjamin Goluboff examines the use of the picturesque in eighteenth- and nineteenth-century travel writing and traces its intellectual origins to writings by Edmund Burke, Uvedale Price and Richard Payne Knight. Among these writers there is frequent argument as to whether this quality belongs naturally to the landscape or whether it is constructed by a viewer trained in the art of composition: "the picturesque for Knight was not so much an objective quality existing in a scene, but a manner of seeing nature with an eye educated in the compositional principles of seventeenth-century landscape painting". For travel writers who shared this view, the goal was to provide the traveller in search of such prospects with instructions and advice "as to how the picturesque might be identified and stalked" (1991, 6-7). 
The aims of the guidebook, at least at its earliest form, were more modest. As Lynne Withey explains in her introduction to the genre, the guidebook's purpose was originally conceived to be the provision of information rather than education, its function to communicate bare facts and practicalities rather than to entertain or offer lessons in the correct means of approach to a scene. By the end of the nineteenth century, however, there had been a gradual expansion in the educational remit of guidebooks. No longer, as they had been in the 1820s, simply "point-by-point descriptions of routes, methods of transport, and accommodation", these new guidebooks were also primers covering local and national history, anthropology and, above all, art history (Withey 1998, 68-9). J.M. Dent's turn-of-the-century series on medieval towns, for example, was addressed to a reader who saw herself both as tourist and amateur historian. The preface to The Story of Florence promises "a popular history of the Florentine Republic, in such a form as it can also be used as a guidebook". The author claims to have improved on the guidebook-by giving more of the "historical atmosphere of Florence and her monuments than guide-books and catalogues can supply" - even as he admits his debts to the Baedeker as regards "the domain of topography" (Gardner 1900, vii-viii). ${ }^{3}$

Baedeker handbooks were themselves aimed at a readership newly understood to be amateur contributors to, as well as consumers of, a knowledge economy. In the preface to the Handbook to London owned by both Eliot and Forster, the editor explains that the books are designed with both the entertainment and the education of the reader in mind: "The chief object of the Handbook for London is to enable the traveller so as to employ his time, his money and his energy, that he may derive the 9 
greatest amount of pleasure and instruction from his visit" (Baedeker 1908, v). The words are sometimes varied but the promise to provide pleasure and instruction remains the same across many different editions of the Baedeker. ${ }^{4}$ It recalls the classic defence of literature and art seen in Horace (and many others since) and the Baedeker gains in stature by means of the association. In Ars Poetica, Horace demands that art should instruct and give pleasure, while in "The Defence of Poesy" Philip Sidney states famously that the aim of poetry was to "teach and delight" (Sidney 1989, 217).

The Baedeker signals its literariness in other ways too. In the frontismatter of late nineteenth and early twentieth-century Baedekers the editors include an envoi which, although usually found at the end not the beginning of a book, is otherwise true to form in begging a generous reception and gentle correction from its readers. In an early 1890 s edition of the guide to Italy, the envoi is misattributed to Chaucer but in later editions it seems to have been subject to a correction of its own and the name of the author is given as Sir Richard Ross:

Go little book, God send thee good passage,

And specially let this be thy prayere

Unto them all that thee will read or hear:

Where thou art wrong, after their help to call,

Thee to correct in any part or all. (Baedeker 1930$)^{5}$

The origins of the envoi are found in the French courtly tradition of troubadour poetry. In the Baedeker, however, it becomes something altogether less aristocratic. Firstly, it suggests a schoolmaster-like familiarity with the canon of English literature; the language is old-fashioned but would be recognisable to anyone who had read the 10 
Oxford Book of Verse. Secondly, its observation of non-standardised spelling, which is more faithful in some editions than others, connotes a touristic as much as an academic sensibility; it chimes with the "Ye Olde Shoppes" encountered by J.B. Priestley on his 1930s tour of the Cotswolds, one of which, he says, "proudly announced that it had been established in the Nineties" $(1949,58)$. And thirdly, as Ezra Pound's inclusion of an "envoi" in "Hugh Selwyn Mauberley" reveals, in modern usage this highly mannered verse, and the world of courtly ritual and convention it invokes, cannot help but sound ironic.

Such ironies make it difficult to gauge the nature of the claims made by and on behalf of the Baedeker to be a means to, and itself a marker of, culture. On the one hand, the guidebook speaks to a long tradition in which art and literature are at once entertaining and improving, and it draws on propaedeutic and aesthetic codes proper to this mode. This is a paternalistic tradition, especially as represented by Sidney and Ross, and it seems curiously fitted to the Baedeker which adopts a fatherly or avuncular tone in addressing its readership, especially those of a "delicate constitution" who are respectfully advised to insist on a room with a Southern aspect and take an extra coat or shawl to wear in "museums, churches, mosques, and other buildings with stone pavement as the air is often very chilly" (Baedeker, 1911, xv). On the other hand, the guidebook realises a modern ethos in which anyone can find his or her own way to culture provided, that is, that it is packaged in an accessible way_-"popular history in the form of a guidebook" (Gardner 1900, vii). It is possible, then, to see the guidebook as perpetuating cultural conservatism and as the product of a new democratic spirit in modern culture. Neither view, however, would seem to 11 
allow for an easy accommodation with modernism. On the one hand, the guidebook is not innovative enough and, on the other, it takes innovation altogether in the wrong direction; as noted earlier, Baedeker-learning rubs against the grain of modernism as an incipient institution with its own specialist language and particular expertise in the matter of modern culture. Yet this is to anticipate too much because, while both arguments are certainly made, they do not exhaust the many possible ways in which the Baedeker might be invoked to serve modernist ends.

Modernists frequently consulted guidebooks in order to plan their own travels and, as archives and memoirs reveal, many of them were avid readers of the Baedeker in particular. T.S. Eliot, for example, owned and annotated a copy of The Handbook to London and its Environs (1908), which is now held in the Papers of the Hayward Bequest at King's College Cambridge. A series of ticks and a list of sights inside the back cover confirm that his interests lay in churches, museums and the literary history of the city. King's College also holds a collection of the Baedekers owned by E.M. Forster and, although these contain fewer annotations, an unknown hand has added some helpful advice to Forster's copy of the Handbook to Southern Italy and Rome: "Do not go to Capri if rough, as Blue Grotto unless quite calm." ${ }^{6}$ Ezra Pound's Malatesta Cantos rework a Romantic interpretation of the tomb of Isotta degli Atti, which, as Lawrence Rainey points out, was "diffused through books and studies of every sort: novels, travel guides, encyclopaedias and scholarly monographs" (1991, 36). Rainey makes particular reference to the 1908 guide to Central Italy and Rome which Pound took with him on his first visit to the tomb in 1922: "I HAVE brought the Baedeker so don[']t worry about that" (as quoted in Rainey 1991, 254 n15). H.D. 12 
had a particular attachment to her guidebook too and, according to friends, would frequently wander around foreign cities as if "religiously transported" by Baedeker (Guest, 104). We know from the records of Bryher's library that H.D. owned at least three - the Handbooks to Italy, Northern Italy and to Egypt and the Sudan-and, as I suggest below, she used these books as inspiration for her fiction (Smyers 2001). That modernist authors were keen readers of guidebooks proves little, however, beyond the fact that they were very much men and women of their time. More suggestive of the particular significance of the guidebook is the way these authors frequently condescend to the Baedeker expert even when they have little more than their own Baedeker-learning on which to rely for information about a place.

The function of the guidebook

The typical Baedeker scene in the modernist novel serves to underline the difference between tourism and the kind of travelling which offers acculturation, individual fulfilment and the kind of transformative experience associated with the pilgrimage. The distinction is as old as tourism itself, but it gains traction in the late nineteenth and early twentieth centuries from the overlap with other much-discussed cultural divides such as individual/crowd, elite/mass and expert/consumer. As Dean MacCannell and James Buzard have pointed out, the discovery that one's new experiences as a traveller are the common-or-garden experiences of the crowd that has passed that way before produces "touristic alienation", a sense of belatedness and a determination to find some "saving difference from the mob" (MacCannell 1999, 49, 107; Buzard 1993, 90, 82). Modernist fiction proves a rich source of examples of 13 
"touristic alienation", which, although not so familiar as examples of urban alienation, often serve a similar function: by means of contrast to the tourist crowds, the modernist protagonist is revealed to be a man or woman of enquiring intellect (unlikely, therefore, to be satisfied with the received-view of a place), discerning tastes in art and culture and keen sensitivity to the atmosphere and environment. The kind of man or woman, in other words, who might plausibly see, hear, feel and think to the depth and with the intensity often showcased in the modernist novel. Virginia Woolf's Jacob's Room, for example, contains a scene at the Acropolis in which Jacob, Baedeker in hand, attempts unsuccessfully to escape the pestering guides, "Ladies with green and white umbrellas" and "Madame Lucien Gravé perched on a block of marble with her kodak". Jacob finds it difficult to reconcile the Greece he discovered at Cambridge with this touristic Greece and is inclined to read the transformation as presaging the fate of another Imperial power: "But then there was the British Empire which was beginning to puzzle him" $(1992,132,121)$. In "Narthex", a short story I discuss in more detail later on, H.D. reveals the social distinctions that are often thinly disguised behind the difference between tourist and traveller. From her position leisurely observing the passers-by in St Mark's Square, Venice, Hermione watches the suburbanites_- "fresh Camberwells and Brixtons"- on a quest to "tick off" the "sights" in Venice (H.D. 1928, 238). Eliot's "Burbank with a Baedeker: Bleistein with a Cigar" trades on similar distinctions. Although the social cues in Eliot's poem speak to an American rather than an English context (Burbank seems, like Eliot himself, a small-town businessman discovering Europe for the first 
time), the Baedeker remains as a transatlantic signifier of a newly aspirant and mobile class.

In these examples, it is the reader of the guidebook rather than the genre itself which is subject to scrutiny; the Baedeker features not on its own merits (or demerits), but rather because it is part of the trappings of tourism. In other scenes of Baedeker reading, however, it is the book itself which seems suspect, especially when judged against its claim to help the traveller find pleasure and instruction. In Ford Madox Ford's The Good Solider, for example, Dowell wonders whether Leonora's impressive knowledge about foreign cities speaks to her remarkable education or to her ability to rapidly memorise the facts as they appear in Baedeker. The second possibility, Baedeker-learning, is clearly less noteworthy than the first: "Leonora herself always struck me as being remarkably well educated. At any rate, she knew beforehand all that Florence had to tell her. Perhaps she got it up out of Baedeker before Florence was up in the morning" (Ford 1946, 42).

Ernest Hemingway has reservations about book-learning in general, which crystallise around the guidebook and, more specifically, the phenomenon of "bookvisiting" whenever it threatens to take the place of first-hand witness. The problem surfaces partway through Hemingway's own guidebook, Death in the Afternoon- the book Carlos Baker called his "Baedeker of the bullfight" (1972, 143). Hemingway interrupts his narrative to explain to his reader how she is and is not supposed to use the guidebook: "There are two sorts of guide books; those that are read before and those that are to be read after and the ones that are to be read after the fact are bound to be incomprehensible to a certain extent before; if the fact is of enough importance 15 
of itself" (1932, 53). Death in the Afternoon seems to combine these two modes; immediately after issuing this instruction, Hemingway tells his reader that the time has come for her to see a bullfight for herself. To continue reading without having done so would presumably mean missing the fact of the fight itself. Hemingway does not consider that the guidebook might be consulted "on the spot", although this is exactly how Forster tells his reader to use his guidebook to Alexandria $(2004,8)$. Death in the Afternoon with its uncharacteristically decorous prose seems poorly designed for this purpose in any case. As suggested by Hemingway's novel, Across the River and into the Trees, the tourist who reads the guidebook in situ risks mistaking his reading about a place or spectacle for the main event.

In that novel, Hemingway establishes a careful distinction between Baedekerlearning and the kind of expertise hard won through experience and first-hand exposure to the "real thing". Across the River is not one of Hemingway's best-known novels, but together with Fiesta it is one of his most powerful when it comes to the evocation of place. The novel follows an American Colonel on his return to Venice after World War One. There he wanders from the hotel, to the restaurant, to the market and back again, sharing with the locals his impressive knowledge of regional produce and keeping a calculated distance from one of the few other Americans in Venice, a Baedeker-reading journalist. A typical scene takes place in the marketplace where the Colonel demonstrates he is a man with discerning tastes, a man with the ability to tell the difference between a sausage and a sausage:

The Colonel liked to study the spread and high piled cheeses and the 16 
Then he said to the woman in the booth, 'Let me try a little of that sausage, please. Only a sliver.'

She cut him a thin, paper thin, slice for him, ferociously, and lovingly, and when the Colonel tasted it, there was the half smokey, blackpepper corned, true flavour of the meat from the hogs that ate the acorns in the mountains. (Hemingway 1994, 139)

The passage showcases Hemingway's considerable skill as a food writer. A run of adjectives (sustained by transforming a noun, black-pepper-corn, to an adjective) suggests an escalation of flavour, which culminates in a taste so "true" that it transports the Colonel back to the Alpine forest in which the meat was reared. The words themselves taste good as Hemingway exploits to the full the guttural and fricative pleasures of "shucked" and "brochetto" and the contrasting languor of "opalescent" and "crustacean". Venice offers the Colonel an aesthetic experience of a particularly sensual and embodied kind and, in an extended metaphor surely meant to foreground the point, the market is transformed into a picture gallery: "[The Colonel proceeded on] looking at the amount of fat on each carcass in the butcher section, as though he were enjoying the Dutch painters [...]. A market is the closest thing to a good museum like the Prado or as the Accademia is now, the Colonel thought" (Hemingway 1994, 140-1). The Colonel is a man of taste, although this should not be taken to mean refinement and connoisseurship, so much as an appetite trained over time to appreciate the very best of the altogether rustic products the region has to offer. 
The contrast with the journalist and his Baedeker could not be more pointed. The Colonel can barely disguise his scorn for the journalist's "book-visiting" and, specifically, his lack of taste: "He speaks bad Italian assiduously. He goes everywhere in Baedeker, and he has no taste in either food or wine" (Hemingway 1994, 91). Taste, which describes here a whole range of attributes from a good appetite (both for sex and food) to a discerning appreciation for art and the artisanal, cannot be booklearned. Further, it seems itself a sign of poor taste to whip out the Baedeker, almost as if it were a gun, at every available opportunity:

'Gran Maestro,' he asked, 'did my illustrious compatriot look up the Barone in Baedeker?'

'Truly my Colonel. I have not seen him pull his Baedeker during the meal.'

'Give him full marks,' the Colonel said. (Hemingway 1994, 96)

Hemingway's emphasis on "taste" and the futility of the attempt to come to culture via the guidebook is very much in the spirit of eighteenth-century travel writing. Although his understanding of taste is altogether more sensual than that of an orthodox Kantian, he retains the idea that the traveller needs to possess good aesthetic judgement if he is to fully appreciate a place. Hemingway's snide remarks about the Baedeker are reminiscent of another long-standing convention of travel writing toothe practice of denigrating the competition as a means of bolstering one's own claim to be the leading authority on a place.

"Baedekeresque" style

18 
A second strand of modernist commentary on the guidebook focuses on the perceived shortcomings of Baedeker style. In this context, it is not just travel writing which serves as the immediate point of comparison but other literary modes too including art-critical writing and fiction. Virginia Woolf sets out the most direct case against guidebook style in "Craftsmanship", originally broadcast on the BBC in 1937. During a wider discussion about what the writer can and cannot do with the medium of language, Woolf pauses to consider what the popularity of the Baedeker, and especially its use of a star-system to mark quality, might mean for the future of criticism. There is, she explains, an inherent slipperiness to language, which she names the "suggestive power of words" $(1942,129)$. The test of a good critic is the manner in which she accommodates to this power. A bad critic inevitably tries to arrest language, to pin words down to things and in so doing reproduces in her writing the phenomenon found in the Michelin Guide or the Baedeker. Language becomes a series of one-to-one correspondences and the art of criticism is by these means reduced to 'a handful of stars':

Baedeker carries the sign language still further into the sublime realms of art. When he wishes to say that a picture is good, he uses one star; if very good, two stars; when, in his opinion, it is a work of transcendent genius, three black stars shine on the page, and that is all. So with a handful of stars and daggers the whole of art criticism, the whole of literary criticism could be reduced to the size of a sixpenny bit--there are moments when one could wish it. (Woolf 1942, 128) 
Woolf's argument is a kind of reductio ad absurdum. She assumes that the Baedeker's attempt to rank as much as possible in as little time as possible amounts to a failure to properly evaluate anything at all. And she extrapolates from this the further consequence that all criticism will one day be replaced by a system of stars and icons. The reasoning is, of course, ridiculous and deliberately so. But it does contain an element of truth, both about the project the guidebook inaugurates, and why it should attract criticism from those concerned for the future of literature.

When H.D. turns to the problem of the guidebook she too sees its "sign-post" language as a degradation of less direct, more literary forms of language. In the Baedeker, language becomes inhuman, a machine calibrated to fix things to words and words to things. So perfectly does the Baedeker exemplify this tendency that H.D. applies the term Baedekeresque anachronistically to describe the work of the Greek traveller, Pausanius:

I should say the most personal remark that we can drag from him; his impersonality is colossal is, I must repeat, Baedekeresque. [...] For if Pausanius for one moment turned from his self-appointed task of a sort of human 'pointer', an inhuman sort of sign-post, a finger tracing for us name after name, river and stone quarry and well-head, how could we further bear it? $?^{7}$

Karl Baedeker claimed to be the first to use the star system. His purpose, as the novelist Alan Sillitoe explains, was "to familiarise his readers with the merits, in general esteem, of the things they encountered on their travels; 'starred in Baedeker' 20 
became a synonym for high quality" $(1995,4)$. For Sillitoe, this method is typical of the drive to economy and the democratisation of genius, which, in his view, constitutes the major achievement of the guidebook. It is tempting to read in reverse here the precise reason that Woolf mistrusted the genre; after all, while Sillitoe first came to prominence as a writer for and about the post-war working class, Woolf is, at best, a writer with an ambivalent relationship to a mass readership; as Melba CuddyKeane explains, her cultural politics amount to a kind of "democratic highbrowism" (2003, 9). And yet Woolf seems altogether less concerned by the fact that the guidebook makes genius accessible to everyone than by the fact that it sells such genius desperately short: "it is a work of transcendent genius, three black stars shine on the page" $(1942,128)$. Woolf's own criticism appeared in a whole variety of contexts including Cosmopolitan, Good House-Keeping and Vogue and, as CuddyKeane points out, her recommendation for readers of all types and backgrounds was extensive reading in all kinds of literatures (2003, 171-174). Perhaps, then, it is less the lowbrow nature of the guidebook to which Woolf objects, than its drive to economy: its attempt to save the traveller the time and expense it would require to undertake a preparatory study of the literature about the monuments and sights on her itinerary.

Few modernists are quite so direct as Woolf in discussing the impact of the guidebook on the art of criticism. Nonetheless, her questions about the guidebook frequently recur. What exactly is the difference between art criticism and the functionalist criticism found in Baedeker? What is its impact on the reader's capacity to arrive at an independent aesthetic judgement? And what is the fate of 'transcendent 
genius' when subject to the rating system pioneered in Baedeker? For Hemingway, in the example seen above, the Baedeker appeals only to the bookish and those of questionable taste who invariably struggle to appreciate the true art of a place. In parts of H.D., Loy and Forster, however, this situation is turned on its head: the world as given in the Baedeker is one that appeals primarily to the aesthetic judgement before the understanding and it does so precisely because the guidebook stretches reason to its limits. These writers still have much to say about the shortcomings of the guidebook as a means to culture but it is not so certain in their writing that the guidebook is not itself already a form of literature.

The Laws of Time and Space

E.M. Forster offers the most direct answer to the question of whether the guidebook counts as literature in a lecture on the writing of Alexandria: A History and a Guide delivered in Aldeburgh on 17 June 1956. It does, Forster concludes, but only if we concede that the category contains altogether more sub-varieties than is usually the case: "I have always been interested in Guide Books. For me they constitute a branch of literature that follow their own laws" (2004, 351-359). Forster attributes a special licence to the guidebook and, although he does not here specify in what that might consist, he seems already at odds with the received-view of the guidebook as a dry repository of facts (Lisle 2006, 30). As mentioned at the beginning of this article, it is facts which often prove decisive when guidebooks are tested against more conventional branches of literature and found wanting. In Alexandria, however, facts appear altogether less restrictive than is usually assumed to be the case. The problem 22 
with Alexandria, Forster explains, is that the modern city is bound to disappoint the traveller acquainted with the romance of its history and reputation. She would be well advised, then, to turn to the past as a means of compensating for the present: "The 'sights' of Alexandria are in themselves not interesting, but they fascinate when we approach them through the past" $(2004,7)$. Alexandria is divided into two sections, a History and a Guide, with a system of cross-references to aid the reader in mapping the history on to the modern city. This structure would seem to get around the problem of bare facts and practicalities by holding them over until the second section of the book.

Forster's own "superior" guidebook would seem, then, to improve on the ordinary kind. But it is not clear that he sees facts as the main shortcoming of the ordinary guidebook either. Where Angels Fear to Tread opens with an invented entry from The Handbook to Central Italy which serves to introduce the Tuscan town in which part of the action is set: "The traveller will proceed direct from the Siena gate to the Collegiate Church of Santa Deodata, and inspect ( $5^{\text {th }}$ chapel on the right $)$ the charming Frescoes" (1959, 16-17). The narrative looks set to continue in guidebook idiom as Philip arrives at his destination and is faced with the prospect of a difficult transfer to the village: "When the bewildered tourist alights at the station of Monteriano, he finds himself in the middle of the country. [...] He must take what is suitably termed a 'legno' - a piece of wood - and drive up eight miles of excellent road into the middle ages." But this is not what happens. Instead, the author intervenes to remind the reader, too easily charmed by such things, that in reality "it is impossible as well as sacrilegious to be as quick as the Baedeker" (Forster 1959, 20). 
Here Forster suggests that the very things that literary-minded critics deride in the guidebook - economies of scale and time-produce fantastical versions of the world that are "impossible" to find or replicate in reality. The guidebook is revealed to have an unexpected affinity with fiction in that, it too, has special license to play fast and loose with physical and, as the word "sacrilegious" suggests, with metaphysical laws.

Forster's novels recognise the literary potential of the guidebook at the same time, then, as its potential to deceive or misguide (it approximates "fiction" in two senses, being both literature and a false account of the world). Like Woolf, Forster is particularly concerned about the guidebook's cavalier treatment of transcendent things, although in his view it is the genius loci rather than creative genius that receives short shrift at the hands of Baedeker. To travel from A to B too quickly in his novels is to ignore the ambiguous power of the res sacrae, a power whose strength seems to increase in inverse proportion to the amount of space a place is afforded in the book. The much-quoted first line of Passage to India is a case in point. Adela meets her mysterious fate in caves which, if abandoned to the idiom of the guidebook, would hardly figure at all: "Except for the Marabar Caves - and they are twenty miles off - the city of Chandrapore presents nothing extraordinary" (Forster 2005, 5). A Room with a View offers several comic examples of the same guidebook-induced sacrilege; Lucy looks on with embarrassment, for example, as a family of Catholics accidentally worships at the tomb of Machiavelli (Forster 1978, 41). Forster is by no means hostile to tourism and its effects. On the contrary, as Andrew Thacker points out, he seems fascinated by the new processes of "spatial production" revealed by modern means of transport and incorporates these processes into the interior space of 
his novels $(2000,45-46,49)$. The guidebook represents a special kind of opportunity related closely to Forster's own ambitions as a writer with a particular interest in travel and place. The exceptional properties of this literature, which include special license to disregard the laws of physics and metaphysics, throw into sharp relief Forster's own reverence for place in both its material and spiritual aspects.

\section{Supersensible form}

H.D. rehearses many of the arguments already seen in Woolf, Hemingway and Forster. She finds fault with the "impersonal" style of the "Baedekeresque", which misses "the aura, the depth of beauty, the almost unbearable compass of these places", dismisses its readers as surburbanites, and, as indicated by the quotation I borrowed for the title of this article, despairs of anyone ever finding beauty with the aid of guides and guidebooks: "O God don't let me pity them, looking all lost towards a Cook's guide for beauty" ("Notes on Euripides, Pausanius and Greek Lyric Poets", 20). As the quotations suggest, H.D. frequently queries whether the guidebook is a reliable source of good aesthetic judgement and whether it can act as an encouragement to such on the part of the tourist. At issue is no longer just whether the guidebook peddles second-hand sights and experiences, but whether it aids the tourist in her quest for the sublime ("the unbearable compass") and the beautiful. Although, in the statements quoted above, H.D. seems certain that there is nothing to exercise the aesthetic judgement in the Baedeker, the use that she makes of these same guidebooks in her fiction suggests otherwise. Here, as in the poetry of Mina Loy, the 
Baedeker offers lessons in how to approach the "given infinite" which is an embodiment of the Kantian sublime.

How, then, might a guide or a guidebook lead the tourist astray in her quest for beauty? In Asphodel (written in 1921-22), Hermione (a thinly disguised version of the young H.D.) encounters a group of tourists from Kansas in the company of their Cook's guide in the Louvre. As they stare at the Venus de Milo, Hermione considers what it is that they are striving so hard, and yet still failing, to comprehend:

The guide was saying 'and here ladies and gentlemen in the glass case at the left' (he never varied this formula) 'you have the authentic fragment of the foot, the bit of the hand and the arm and the lost apple.' How do you know it is an apple, how can you tell it is her hand or her foot? You can't but nobody ever asked such simple questions. They accepted the dogma as good presbyterians, good methodists, good nonconformists or even good catholics have a way of doing without question, without grace or without bickering. How did they come to do it? Religion of love of beauty wasn't this thing. But still they wanted something, looked for something. Oh God don't let me pity them, looking all lost towards a Cook's guide for beauty. (H.D. 1992, 20)

Beauty appears frequently in H.D.'s writing as a form of divine illuminationvision that can only be gained with supernatural assistance. These tourists are "without grace" and therefore, for all that they are willing to accept the word of their guide as to the significance of what they are seeing, they have no means of accessing 
beauty for themselves. In fact, the tourists' very readiness to assent "without bickering" to the guide deepens their predicament because, as Descartes points out, it is impossible to achieve grace by agreeing to arguments in its favour: "If, despite the fact that these doctrines are obscure to him, he is induced to embrace them by fallacious arguments, I make bold to assert that he will not be on that account a true believer, but will instead be committing a sin by not using his reason correctly" (1984, 106). The tourists cannot see, as Hermione claims to be able to, the flaws in the guide's reasoning: "How do you know it is an apple?" And while it might be possible to justify this failure of reason as a gesture of faith in the religion of beauty, Hermione doubts that such a defence is applicable in this case: "Religion of love of beauty wasn't this thing". In the usual order of things (as seen, for example, in Thomas Mann's Death in Venice), common sense would belong to the tourist who reputedly has difficulty seeing beyond the brute facts, while enthusiasm, especially of the quasireligious sort depicted here, would belong to the artist who loses sight of reality in her quest for beauty. H.D. reverses these positions by putting her proxy artist, Hermione, firmly on the side of reason and common sense and showing the tourists in the grip of enthusiasm. The switch is important because, although there is little to recommend tourism here, when H.D. later comes to consider the phenomenon in a more favourable light it is the hyperrational account of the world given in the guidebook that seems most to appeal to her artistic temperament.

H.D.'s use of religious doctrine is an audacious means of separating her own superior vision from that of the tourist. She is not a travel writer in the usual sense, but her novels and stories draw heavily on her own experiences as a traveller and 27 
often feature protagonists who are thinly disguised proxies for the author. It matters, then, that these protagonists seem authentic when describing place and to this end H.D. insists on the usual "saving difference" from the tourist (Buzard 1993, 82). She differs from the likes of Forster, however, by giving full force to the salvation analogy implied in the phrase. In a letter to her cousin Clifford Howard, for example, she recalls a visit to Saint Mark's cathedral in Venice. H.D. later recalls the episode in almost identical terms in her fictional autobiography, The Mystery:

[A]lso did feel I had 'stolen grace', especially in Venice, as I was in Saint Mark's, in one of the corridors, very crowded, could not get through, and pushed right against a rail, I was suddenly astonished to find myself being pontifically blessed by a subtle, charming old gentleman, who, it turned out was the Patriarch of Venice. (H.D. to Clifford Howard, March 17, [1942], H.D. Papers; 2007, 112)

Pericles Lewis notes that modern novels often contain scenes set in chapels or churches, where an encounter with a native worshipper prompts the post-Christian tourist to wonder exactly what remains to move him in such places: "lone male wanderers, often with touristic inclinations, visit churches and puzzle over the question of just what sort of power remains when even disbelief no longer motivates their view of religion” $(2004,670)$. In identical circumstances, H.D. claims access to the power that eludes the tourist without, that is, giving up on her post-Christian privilege of wondering in exactly who or what that power resides. H.D. has "stolen" grace thereby committing the kind of inadvertent act of sacrilege against which the 
Baedeker is careful to warn its readers: "Visitors may inspect the works of art even during service, provided they are very quiet and keep aloof from the altar" (Baedeker 1930, xxviii). Yet, following her blessing, she seems suddenly possessed of a quality of insight and vision which seems altogether worthy of the title of "grace" — "an inner light", which Descartes explains, is "more certain than any light of nature" (1984, 105). The patriarch himself is seen to have a "special glamour" while Venice itself is suddenly bathed in an intense and clarifying light becoming "so distinct" in H.D.'s eyes (H.D. to Clifford Howard, March 17, [1942], H.D. Papers). What began as a touristic inclination is transformed here into "more certain" knowledge of the peculiar beauty of the city, which H.D. alone is privileged to see.

It seems possible, then, to pass between the typical tourist experience and a more rarefied encounter with place understood in non-religious, primarily aesthetic terms. Under such circumstances, the guidebook might also be transformed from a sub-literary form of travel writing into a guide to the exalted realms of art and literature. Mina Loy provides the most obvious example of this transformation in her collection of poems, Lunar Baedecker [sic]. The title poem of this collection is sometimes read as a satirical guide to decadence in which the aesthete's pretensions to immortality and transcendence are systematically reduced to the products of decay and death (Koudis 1980, 100). The artist has more, however, in common with the tourist than this reading suggests. The sites of death and decay in the poem could easily have come straight from a Baedeker itinerary-Pharoah's tombstones, the Necropolis and mildewed museums - and the cosmic attractions of immortality are announced as if they were sideshows in a travelling carnival: "Stellectric signs / 29 
'Wing shows on Starway' / 'Zodiac carrousel'” (Loy 1997, 87-88). Loy shifts rapidly from the universal to the particular, from the cosmic to pragmatic, in a manner that is typical of the guidebook; the word "stellectric", for example, collapses the stars into the electric signboard much as the Baedeker slides awkwardly between Pharoahs' tombs and electric lighting in the example I discuss below. Loy's "house of fame" seems calibrated, then, to appeal to a touristic as much as an artistic sensibility. And like the always-belated tourist the artist is likely to be disappointed in her destination. She has come too late and finds the moon already sullied and marked by the passage of artists before her: "Pocked with personification / the fossil virgin of the skies / waxes and wanes" (Loy 1997, 87-88).

Whereas for Loy, the Baedeker provides metaphors for art, for H.D. it provides something more substantial: namely, formulae by which the tourist's intuition of the world (a list of prospects and monuments to be seen) might be transformed into a felt sensation of the infinity of the sensible world. I am using Kantian language here but this experience is not strictly that of Kant's sublime, which as Leask points out has nothing to do with the "spirit of minutiae" found in the guidebook (Kant as quoted in Leask 2000, 41). Rather, the analogy is with Kant's assumption of a "supersensible power" to the human mind required, in The Critique of Aesthetic Judgement, to explain the human ability to apprehend the sublime. Kant argues that when confronted with an object of particular immensity, the imagination can only fail in its attempt to grasp that object in its totality. The imagination has a mathematical quality, it can go on incrementally, ad infinitum, but it cannot come to rest on a final or finite whole. Reason, by contrast, requires totality and it is therefore 30 
by forcing the imagination to accommodate to its demands that it allows us to think the given infinite. As Susan Meld Shell explains, "that the given infinite should be thinkable without contradiction, demands a supersensible power to that effect within the human mind." This power she continues must be felt; the mind "feels expanded [...] without quite seeing where it is going" (1996, 208-209). In H.D.'s less systematic approach, the Baedeker functions like a degraded form of Kant's imagination, gathering up the world incrementally (in the form of the timetable and the itinerary) and seemingly without end. It cannot by itself approximate infinity, which requires the intervention of another faculty within the human mind. H.D. calls this power the "overmind" rather than reason, but its effects are similar: the human mind feels itself expanded beyond the limits of the individual, touching both the edges of other minds at other times and the edges of the infinite $(1988,18-19)$.

In "Secret Name", a short story published as the third part of Palimpsest in 1926, Helen Fairwood visits the Valley of the Kings in the company of a group of American tourists. The episode contains several details from The Handbook to Egypt and the Sudan, a book that H.D. owned and inscribed with her name and the date, January 11, 1923. H.D. seems especially drawn to those details, which, incongruously or anachronistically yoked together in the Baedeker, unintentionally produce comic or dramatic effects. In the section on the Tomb of the Kings, for example, Baedeker seems curiously and repeatedly distracted from the main attraction-artefacts dating back some 3000 years — by the presence of modern lighting:

The most important tombs (Nos. 6, 8, 9, 11, 16, 17, 35) are lighted up by electricity daily.

31 
In the crypt stands the sandstone Sarcophagus of the king (effectively shown by electric light), containing a mummy-shaped coffin with the body of Amenophis II., wrapped in its shroud and still adorned with garlands. (Baedeker 1914, 285, 97)

The observation is not without significance - the lighting of tombs was a new phenomenon in the 1920 s and it is, of course, useful to know that a visitor does not need to bring her own source of light. But in "Secret Name" it becomes entirely fatuous. Helen reports the words of an American tourist with heavy irony: “"Wonderful the lighting of these old tombs with real electricity"” (H.D. 1926, 259) The tourist gaze, so H.D. implies, is all-too-easily misdirected. On other occasions, however, the eclectic nature of the details in Baedeker seems more comfortably accommodated within the novel's own aesthetics. Helen's appreciation of the wonder of the tomb is predicated on a series of awkward transitions between the seeming permanence of the ancient world and the transitory but glittering wonders of the present-day. Thus the gilt decoration of the tomb seems as if it were "laid on yesterday by some skilled quarto-cento craftsman" and the exquisitely etched stars on blue (also mentioned by the Baedeker) are "child's tree ornaments". The episode as a whole concludes with a concentrated image of time in which the Egyptian opal, which Helen feels to be located in her own forehead, opens out into a vista of history with Egyptian opal at one end, the Attic promontory in the middle and "modernity, New York, Mary Thorpe" at the other (H.D. 1926, 260-261). This is the climax of Helen's 
experience in the tomb: a vision, or to return to H.D.'s Overmind, a feeling of the mind's expansion to encompass nothing less than the entirety of human history.

The Baedeker offers further models for how to apprehend objects (and subjects) of great magnitude. As already noted, the guidebook's taste is for minutiae rather than the sublime and it typically conveys size and magnitude through statistics rather than through the impact a building or feature of the landscape is supposed to have on the viewer. On occasion, however, the Baedeker's approach is comparative, suggesting in more or less clichéd fashion how many other large objects could have been contained within the area occupied by a particular landmark. In the guide to Egypt and the Sudan, for instance, the great hall at Karnak is said to be "spacious enough to accommodate the entire church of Notre Dame at Paris" (Baedeker 1914, 286). The image is typically touristic in its frame of reference; it avoids the trap of culturally specific comparisons (that might in the UK, for example, refer to the number of double-decker buses or football pitches which could be fitted into any given space) and instead appeals to the tourist's sense of herself as world citizen. When incorporated into "Secret Name", however, this formula comes to signify something different. Describing exactly the same monument, the banqueting hall at Karnak, H.D. supplements the reference to Paris with one to Greece: "At her back was that enormous Champ-de-Mars like space in which conceivably one might set up the Parthenon and have space left and over for such tiny exquisite toys as the Erechtheum and the tiny Niké" $(1926,304)$. The point here is also "world-citizenship" but not purely in the touristic sense implied by the Baedeker. The image of the Parthenon dwarfed by Karnak is consonant with a pattern in "Secret Name" in which 33 
Egypt comes to supplant Greece as the origin of moral conscience and civilization. H.D. borrows the Baedeker's touristic frame of reference, but then modifies its contents to express her sense of a unified and total culture to which the individual gains access in moments of sudden intuition or revelation.

H.D. discovers in the Baedeker a ready-made mechanics for turning space, global in scale, into form. In the guidebook, the whole world is arranged in horizontal relation as if on a flat plane akin to the map or the itinerary. In "Secret Name" the mechanics are similar but reversed: H.D. works at the edges of guidebook logic to unfold a total space which is felt rather than processed or sequenced and which envelops rather than extending into infinitude (the "given infinite"). This is plausibly the fourth dimension to which Jameson refers in his explanation of the "extra-literary" problem, which produces modernist style. From the metropolis, he points out, it is not possible to glimpse the extent of the colonial system on which the city depends; the global space of imperialism is thus like a "fourth dimension [which] somehow constitutively escapes you". The aesthetic or moral totality seen, for example in Woolf and Forster, is an attempt to compensate for the lack of a complete picture: "Because in the imperial world system this last [national daily life] is now radically incomplete it must by compensation be formed into a self-subsisting totality" (2006, $158,163)$.

If the guidebook sets a certain standard for creating a "self-subsisting totality" however, it is not always one that modernist writers seem inclined to follow. H.D. and Forster both observe that in the Baedeker time is reduced to space and that the result is a set of formal effects that have no real-world equivalent. But they give a mixed 34 
response to this innovation and, in adapting the Baedeker for their own use, they frequently add the temporal or historical dimension missing from the guidebookeffectively, a vertical axis to cut across the guidebook's flat horizontal plane. As noted earlier, Forster is quick to point out that in Baedeker, and only in Baedeker, is it possible to travel "up eight miles of excellent road into the middle ages" $(1959,20)$. H.D., meanwhile, corrects the Baedeker's disregard for actuality by importing recent historical events into what would otherwise be timeless guidebook scenes. In The Handbook to Northern Italy, for example, the pigeons in St Mark's Square are witnesses to the fact that the passage of time has left Venice unchanged: "The countless PIGEONS (colombi, piccioni), ... since ancient times have nested in the nooks and crannies of the surrounding buildings" (Baedeker 1930, 354). In "Narthex", by contrast, the pigeons are very much time-bound, appearing firstly as a symbol of a crisis overcome and secondly as harbingers of a crisis yet to unfold: H.D. reports that "the tourist word on the street" is that Austrian bombs did not kill a single pigeon in WWI; later, she suggests that the black-shirts in St Mark's Square should be "shooed off like pigeons" (H.D. 1926, 237). There is an irony here, of course, because the guidebook is required to be immediately responsive to political and historical events, especially in so far as these events impact on the traveller's security or on territorial boundaries. As the editor of the 1930 Handbook to Northern Italy explains, it was necessary after the war to start the guide again from scratch: "the drastic changes that have taken place since the Great War have necessitated a particularly thorough revision with the result that the book has had to be completely rewritten" (Baedeker 1930, v). In her improvements on the guidebook, however, H.D. brings these drastic 35 
changes into the open and in so doing acknowledges the impossibility of the guidebook's task; the attempt to organise and sequence a space, global in scale, which as Jameson puts it "constitutively escapes you" $(2006,158)$.

These final examples bring into closer focus a tendency seen throughout modernist responses to the guidebook. They frequently offer a critique of the very project with which modernism has sometimes been identified: the modernisation of literature. From Woolf's suggestion that Baedeker takes criticism into the "sublime regions of art", through Forster's idea that we need different laws to account for this branch of literature and H.D.'s Baedeker-inspired vision of a totalised world, the guidebook is made to seem the very latest thing in travel writing and fiction. It sets new standards for content (accessible expertise), for style (sign-post language) and, as seen in this last section, for form (self-subsisting totality). This is perhaps the only constant in modernist responses to the Baedeker which are otherwise sharply divided over whether the guidebook is a sub-literary genre or a hypermodern literature of the future. The very difficulty of placing the guidebook in the hierarchy of literature makes it the perfect test case for wider arguments about what meaning that hierarchy retains in the modern context.

Baedeker. 1886. Italy: Handbook for Travellers, First Part, Northern Italy, $7^{\text {th }}$ rev. ed. Leipsic: Baedeker.

Baedeker. 1892. Italy: Handbook for Travellers, First Part, Northern Italy, $9^{\text {th }}$ rev. ed. Leipsic: Baedeker. 
Baedeker. 1900. Italy: Handbook for Travellers, Third Part, Southern Italy and Sicily, $13^{\text {th }}$ rev. ed. Leipsic: Baedeker.

Baedeker. 1908. London and its Environs: Handbook for Traveller, $15^{\text {th }} \mathrm{rev}$ ed. Lepzig: Baedeker.

Baedeker. 1911. The Mediterranean: Seaports and Sea Routes including Madeira, the Canary Islands, the Coast of Morocco, Algeria and Tunisia: Handbook for Travellers. Leipzig: Baedeker.

Baedeker. 1914. Egypt and the Sudan: Handbook for Travellers, 7th ed. Leipzig: Baedeker.

Baedeker. 1930. Northern Italy, including Ravenna, Florence and Pisa: Handbook for Travellers, 15th rev. ed. Leipzig: Baedeker.

Baker, Carlos. 1972. Hemingway: The Writer as Artist, $4^{\text {th }}$ ed. Princeton: Princeton University Press.

Booth, Howard J and Nigel Rigby, eds. 2000. Modernism and Empire. Manchester: Manchester University Press.

Buzard, James. 1993. The Beaten Track: European Tourism, Literature and the Ways to Culture, 1880-1918. Oxford: Clarendon.

Carr, Helen. "Modernism and Travel (1880-1940)." In The Cambridge Companion to Travel Writing, edited by Peter Hulme and Tim Youngs, 70-86. Cambridge: Cambridge University Press.

Cucullu, Lois. 2004. Expert Modernists, Matricide and Modern Culture: Woolf, Forster, Joyce. Basingstoke: Palgrave Macmillan. 
Cuddy-Keane, Melba. 2003. Virginia Woolf, the Intellectual and the Public Sphere. Cambridge: Cambridge University Press.

Descartes, René. 1984. The Philosophical Writings, translated by John Cottingham, Robert Stoothoff and Dugald Murdoch. Vol. II. Cambridge: Cambridge University Press.

Farley, David. 2010. Modernist Travel Writing: Intellectuals Abroad. Columbia: University of Missouri Press.

Field, Allyson Nadia. 2006. "Expatriate Lifestyle as Tourist Destination: The Sun Also Rises and Experiential Travelogues of the Twenties." The Hemingway Review 25: 29-43.

Ford, Ford Madox. (1915) 1946. The Good Soldier: A Tale of Passion. London: Penguin.

Forster, E.M. (1905) 1959. Where Angels Fear to Tread. London: Penguin.

Forster, E.M. (1908) 1978. A Room with A View. London: Penguin.

Forster, E.M. 2004. "The Lost Guide.” Appendix C in Alexandria: A History and a Guide and Pharos and Pharillon edited by Miriam Allott, 351-9. London: Deutsch.

Forster, E.M. (1924) 2005. Passage to India, edited by Oliver Stallybrass. London: Penguin.

Fussell, Paul. 1980. Abroad: British Literary Traveling Between the Wars. Oxford: Oxford University Press.

Gardner, Edmund G. 1900. The Story of Florence. In The Medieval Towns Series. London: J.M. Dent. 
Goluboff, Benjamin. 1991. "The Problems of the Picturesque: NineteenthCentury American Travellers in Britain.” New Orleans Review 18: 5-16.

Guest, Barbara. 1985. Herself Defined: The Poet H.D. and her World. London: Collins.

H.D. 1926. Palimpsest. Paris: Contact Editions.

H.D. 1928. "Narthex." In The Second American Caravan, edited by Alfred Kreymborg, Lewis Mumford and Paul Rosenfeld, 225-284. New York: Macaulay.

H.D. 1988. Notes on Thought and Vision and the Wise Sappho, edited by Albert Gelpi. London: Peter Owen.

H.D. 1992. Asphodel, edited by Robert Spoo. Durham: Duke University Press, 1992.

H.D. 2007. The Mystery (Synthesis of a Dream) by Delia Alton, edited by Cynthia Hogue and Julie Vandivere. Gainesville: University Press of Florida.

H.D. Papers. Yale Collection of American Literature, MSS 24. Beinecke Rare Book and Manuscript Library, New Haven, CT.

Hemingway, Ernest. 1932. Death in the Afternoon. London: Scribner.

Hemingway, Ernest. 1994. Across the River and Into the Trees. London: Arrow.

Jameson, Fredric. 2007. "Modernism and Imperialism". In The Modernist Papers, 152-169. London: Verso.

Korte, Barbara. 2000. English Travel Writing from Pilgrimages to Postcolonial Explorations, translated by Catherine Matthias. Houndmills: Macmillan. 
Koudis, Virginia M. 1980. Mina Loy: American Modernist Poet. Baton Rouge: Louisiana State University Press.

Lawrence Rainey. 1991. Ezra Pound and the Monument of Culture: Text, History and the Malatesta Cantos. Chicago: University of Chicago Press.

Leask, Nigel. 2000. Curiosity and the Aesthetics of Travel Writing, 17701840: "From an Antique Land”. Oxford: Oxford University Press.

Lewis, Pericles. 2004. "Churchgoing in the Modern Novel." Modernism/Modernity 11: 669-94.

Lisle, Debbie. 2006 The Global Politics of Contemporary Travel Writing. Cambridge: Cambridge University Press.

Loy, Mina. 1923. Lunar Baedecker [sic]. Dijon: Contact, 1923.

Loy, Mina. 1997. The Lost Lunar Baedeker. Manchester: Carcanet.

MacCannell, Dean. 1999. The Tourist. New York: Schocken.

McDonald, Gail. 1993. Learning to be Modern: Pound, Eliot and the American University. Oxford: Clarendon Press.

Peat, Alexandra. 2010. Travel and Modernist Literature: Sacred and Ethical Journeys. New York: Routledge.

Priestley, J. B. (1934) 1949. English Journey. London: Heinemman.

Rainey, Lawrence. 1998. Institutions of Modernism: Literary Elites and Public Cultures. New Haven: Yale University Press.

Rainey, Lawrence. 2005. Revisiting the Waste Land. New Haven: Yale University Press. 
Rosenquist, Rod. 2009. Modernism, the Market and the Institution of the New. Cambridge: Cambridge University Press.

Shell, Susan Meld. 1996. The Embodiment of Reason: Kant on Spirit, Generation, and Community. Chicago: University of Chicago Press.

Sidney, Philip. 1989. “The Defence of Poesy.” In Sir Philip Sidney: A Critical Edition of the Major Works, edited by Katherine Duncan-Jones, 212-50. Oxford: Oxford University Press.

Sillitoe, Alan. 1995. Leading the Blind: A Century of Guidebook Travel 18151914. London: Macmillan.

Smith, Stan. 2004. "Burbank with a Baedeker: Modernism's Grand Tours." Studies in Travel Writing 8 (1): 1-18

Smyers, Virginia. 2001. “H.D.’s Books in the Bryher Library.” Accessed October 31, 2013 http://www.imagists.org/hd/hdvs121.html.

Thacker, Andrew. 2000. "E.M. Forster and the Motor Car." Literature and History 9: 37-52.

Withey, Lynne. 1998. Grand Tours and Cook's Tours: A History of Leisure Travel, 1750-1915. London: Aurium.

Woolf, Virginia. 1942. "Craftsmanship." In The Death of the Moth and Other Essays, 126-132. London: Hogarth.

Woolf, Virginia. (1922) 1992. Jacob's Room, edited by Sue Roe. London: Penguin. 
Youngs, Tim. 2010. “Travelling Modernists." In The Oxford Handbook of Modernisms, edited by Peter Brooker, Andrzej Gasiorek, Deborah Longworth and Andrew Thacker, 267-280. Oxford: Oxford University Press.

Books from T.S. Eliot's Library. The Papers of the Hayward Bequest of T.S. Eliot Material, no. 4, London and its Environs. Archives Centre, King's College, Cambridge.

${ }^{1}$ The Baedeker is name-checked so often in modern literature that any list must be partial. Some of the most prominent references are found in the titles of poems by T.S. Eliot, "Burbank with a Baedeker: Bleistein with a Cigar", and Mina Loy, "Lunar Baedeker", which provided the title of the only collection of poems published during her lifetime, Lunar Baedecker [sic]. References to the Baedeker within writing by E.M. Forster, H.D., Ernest Hemingway and Virginia Woolf are given later in this article.

${ }^{2}$ See Barbara Korte for a more nuanced overview of the shifts in voice and perspective in travel writing over the centuries (2000).

42 
${ }^{3}$ I am very grateful to Stan Smith for drawing my attention to the Medieval Towns Series as a good example of an art-history textbook and guidebook from this period.

${ }^{4}$ See for example the $7^{\text {th }}(1886)$ and $9^{\text {th }}(1892)$ editions of The Handbook to Northern Italy: "The objects of the Handbook for Italy, which consists of three volumes, each complete in itself, are to supply the traveller with some information regarding the culture and the art of the people he is about to visit, as well as regarding the natural features of the country to render him as independent as possible of the services of guides and valets-de-place, to protect him against extortion and in every way to aid him in deriving enjoyment and instruction from his tour in one of the most fascinating countries in the world" (Baedeker 1886, v; Baedeker 1892, v).

${ }^{5}$ The version quoted here is taken from the 1930 (15 $5^{\text {th }}$ ed.) of The Handbook to Italy where it is correctly attributed to Sir Richard Ross. The earlier editions (1886 and 1892) use a different, partially standardised, spelling and the $1886\left(7^{\text {th }}\right)$ edition wrongly attributes the quotation to Chaucer. The attribution has disappeared by the time the $1892\left(9^{\text {th }}\right)$ edition is published. 
${ }^{6}$ Handwritten note on the inside front cover of E.M. Forster's copy of Italy: Handbook for Travellers (Baedeker, 1900). Held by the Archives Centre, King's College, Cambridge UK.

7 “Notes on Euripedes, Pausanius and Greek Lyric Poets", Part II-III, second typed draft, corrected by NH Pearson, n.d., p. 68. In H. D. Papers. Yale Collection of American Literature, MSS 24. Beinecke Rare Book and Manuscript Library, New Haven, CT. Fol. 1120. By H.D. (Hilda Doolittle), from New Directions Pub. acting as agent, copyright (C 2005 by The Schaffner Family Foundation; used by permission of New Directions Publishing Corporation, agents. Reprinted by permission of New Directions Publishing Corp. 